\title{
APLIKASI MOBILE KOMUNITAS GERAKAN BANTU SERIBU ANAK ASUH (GBSA) DENGAN CLIENT SERVER BERBASIS ANDROID
}

\author{
Amras Mauluddin', Uray Yufikar ${ }^{2}$ \\ Program Studi Informatika \\ Universitas Langlangbuana \\ Email : amrasmauluddin@gmail.com ${ }^{1}$, yufikar@gmail.com ${ }^{2}$
}

\begin{abstract}
Currently education and poverty is a problem as it gives an enormous impact on people's lives. As we can see, the number of school dropouts has increased every day. Seeing this condition, Gerakan Bantu Seribu Anak Asuh (GBSA) is present to participate to help children who are less fortunate, to be able to stay in school. Gerakan Bantu Seribu Anak Asuh (GBSA) is a social community that bridges donors and children who are less fortunate to get help. In reality this donation management faced several obstacles both in terms of data management to the confirmation process donations made by donors each donating.

Therefore, by presenting the android-based mobile applications is expected to be a solution to help officers GBSA share information and manage the donations were mandated as well as for donors could further facilitate the process of sharing and confirmation. Applications software development methods that will be used the method of Rapid Application Development (RAD). This method is one method used to develop apalikasi android with short cycles thereby enabling much faster.

After testing with a method black box can be concluded that the system is in conformity with the expected goals.
\end{abstract}

Keywords: Thousand Help Foster Children Movement, GBSA, foster children, donation, android, client server, donations

\section{PENDAHULUAN}

Saat ini pendidikan dan kemiskinan merupakan suatu permasalah yang memberikan dampak yang sangat besar untuk kehidapan masyarakat. Hal ini dapat terlihat dari angkat anak putus sekolah yang semankin meningkat setiap harinya hingga hasil penelitian yang dilakukan oleh UNICEF ditahun 2012 menunjukan bahwa ada sekitar 2,3 juta anak di Indonesia putus sekolah. Melihat kondisi demikian, komunitas Gerakan Bantu Seribu Anak Asuh ini hadir untuk turut berpartisipasi untuk membantu anak yang kurang beruntung, untuk dapat terus bersekolah. Gerakan Bantu Seribu Anak Asuh (GBSA) adalah sebuah komunita sosial yang membantu anak-anak yang kurang beruntung untuk mendapatkan bantuan uluran tangan dari kita. Selama ini, 
untuk memberikan informasi mengenai calon anak asuk kepada donatur yang ingin menjadi orang tua asuh dilakukan melalui sebuah website. Namun, dengan cara berikut, terdapat beberapa kendala, salah satunya adalahdalam mengakses informasi mengenai GBSA harus dengan mengunjungi websitenya dan tidak ada notifikasi kepada para donatur atau calon donatur, pada website GBSA belum terdapat fungsionalitas yang dapat menginformasikan rekap donasi dan dalam proses konfirmasi donasi donatur hanya dapat melalui website atau secara manual menghubungi kontak senter GBSA.

\subsection{Rumusan Masalah}

Rumusan masalah pada aplikasi komunitas Gerakan Bantu Seribu Anak Asuh yaitu diantaranya yaitu:

1. Bagaimana calon donatur dapat lebih mudah dalam mendapatkan informasi anak asuh di GBSA?

2. Bagaimana cara yang untuk lebih memudahkan donatur untuk dapat mengakses informasi mengenai GBSA dimana saja dan kapan saja?

3. Bagaimana caranya untuk dapat memudahkan donatur dalam melakukan konfirmasi setelah mereka melakukan transfer?

4. Bagaimana donatur dapat lebih mudah melihat laporan donasi yang telah dilakukan?

\subsection{Tujuan Penelitian}

Tujuan dari Aplikasi Mobile Komunitas Gerakan Bantu Seribu Anak Asuh (GBSA) Berbasis Android yaitu:

1. Membuat sebuah aplikasi mobile berbasis android untuk membantu donatur mendapatkan informasi seputar bantuan anak asuh di pada komunitas GBSA secara cepat.

2. Memudahkan donatur dalam mengakses segala informasi mengenai GBSA dimana saja dan kapan saja melalui aplikasi mobile android GBSA.

3. Memudahkan proses konfirmasi donasi donatur setelah mentransferkan donasinya.

4. Memudahkan donatur untuk melihat laporan konfirmasi setelah berdonasi. 


\section{LANDASAN TEORI}

\subsection{Gerakan Bantu Seribu Anak Asuh (GBSA)}

GBSA adalah sebuah Komuitas sosial yang bergerak dibidang sosial terutama membantu anak-anak. Komunitas ini terbentuk pada tanggal 14 Januari 2012, tercetus dari beberapa orang yang peduli terhadap anak-anak. Diawal berdirinya komunitasi Gerakan Bantu Seribu Anak asuh ini hanya berupa sekumpulan orang yang dengan rutin membantu anak-anak disekitar dengan bantuan berupa peralatan sekolah. Seriring berjalannya waktu, kelompok ini akhirnya sepakat untuk konsisten membantu anakanak dengan mendirikan Komunitas Gerakan Bantu Seribu Anak Asuh atau dikenal dengan GBSA.

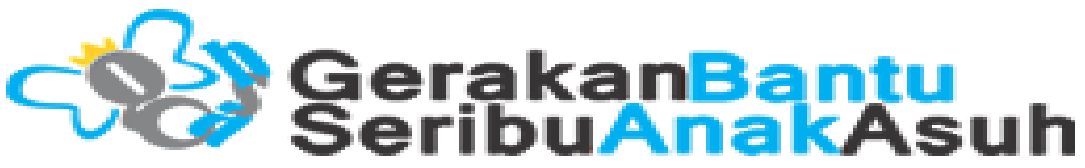

GAMBAR 2.1. Logo Komunitas Gerakan Bantu Seribu Anak Asuh

\subsection{Prosedur Donasi di GBSA}

Komunitasi GBSA menerapkan prosedur dalam proses kerjanya memberikan bantuannya kepada anak-anak yang kurang beruntung yaitu:

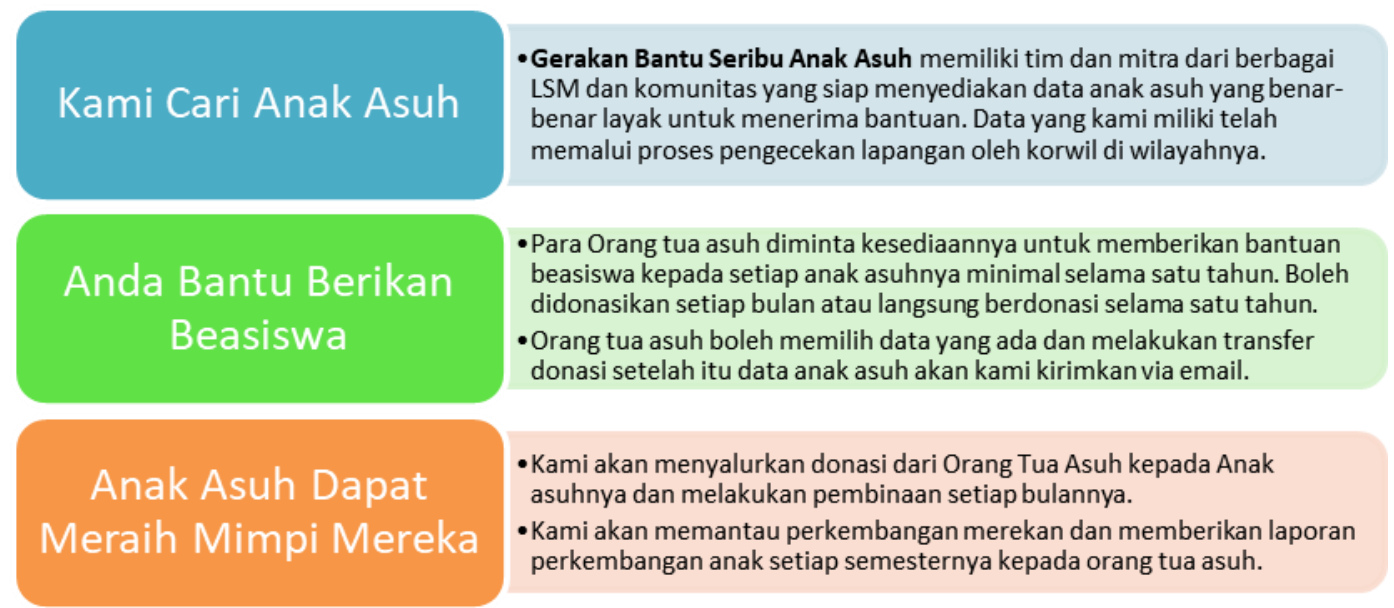

GAMBAR 2.2. Prosedur berdonasi di GBSA

\subsection{Konsep Anak Asuh}

Dalam Islam anak asuh dikenal juga dengan istilah Ihtidhàn. Anak asuh atau

Ihtidhàn adalah menjadikan seseorang yang bukan anaknya untuk dididik, diasuh dan 
diperlakukan dengan baik. Ihtidhan berarti membiarkan anak asuh tetap menggunakan nama aslinya, tidak mengatasnamakan kepada orangtua asuhnya, tidak diwarisi. Semua kebaikan yang diberikan kepada anak asuh hanya sebatas pada pengertian berbuat baik kepada sesama yang memang dianjurkan oleh syari'at Islam. Anak-anak asuh tetap menjadi orang lain. Ia bukan mahram bagi keluarga yang mengasuhnya. Hal itu berarti harus memperlakukan anak asuh sesuai dengan apa yang telah disyari'atkan Islam

Pengertian lainnya dari anak asuh dalam glosarius istilah di kementrian sosial adalahanak yang diasuh oleh seseorang atau lembaga, untuk diberikan bimbingan, pemeliharaan, perawatan, pendidikan, dan kesehatan, karena orang tuanya atau salah satu orang tuanya tidak mampu menjamin tumbuh kembang anak secara wajar. (UU No. 23 Tahun 2002 tentang Perlindungan Anak).

\subsection{RAD (Rapid Application Development)}

Metode pengembangan aplikasi perangkat lunak yang akan digunakan yaitu metode Rapid Application Development $(R A D)$. Metode ini merupakan salah satu metode yang digunakan untuk mengembangkan aplikasi android (Android Mobile Development). Menurut James Martin “Rapid Application Development (RAD) yaitu pengembangan siklus yang dirancang yang dapat memberikan pengembangan yang jauh lebih cepat dan hasil yang lebih berkualitas tinggi dari pada yang dicapai dengan siklus hidup tradisional. Metode pengembangan aplikasi perangkat lunak ini terdiri dari 4 tahapan yaitu Requirements Planning Phase, User Design Phase, Construction Phase dan Cotuver Phase.

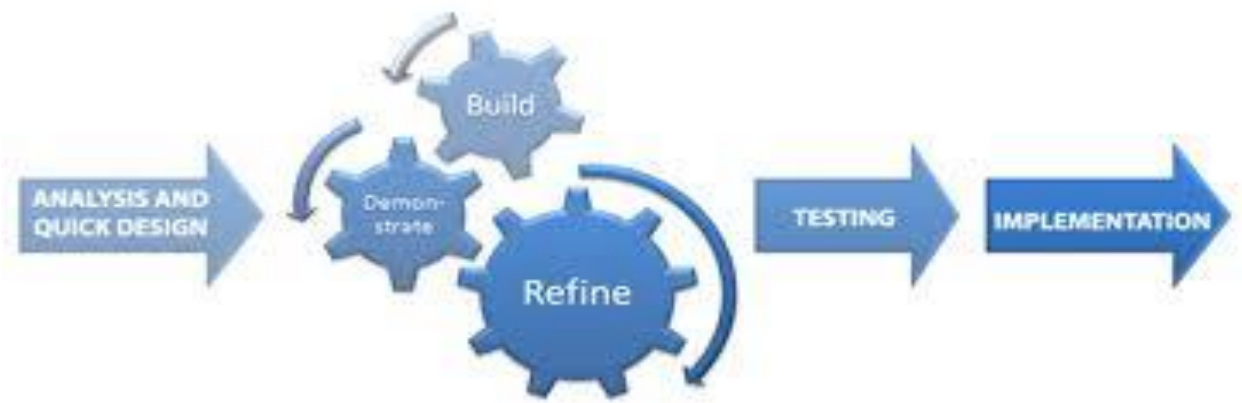

GAMBAR 2.4. Rapid Application Development (RAD)

\subsection{UML}

Unified Modeling Language (UML), UML adalah sebuah bahasa yang sudah menjadi standar dalam industri untuk merancang, menspesifikasi dan mendokumentasi 
sistem perangkat lunak . UML memberikan standar penulisan tersendiri pada sebuah sistem blue print, yang mencakup konsep proses bisnis, penulisan kelas-kelas pada bahasa program yang spesifik, skema database dan komponen-komponen yang dibutuhkan dalam sistem piranti lunak

\subsection{Android}

Menurut Nasruddin Safaat h (Pemrograman aplikasi mobile smartphone dan tablet PC berbasis android 2012:1) android adalah sebuah sistem operasi pada handphone yang bersifat terbuka dan berbasis pada sistem operasi Linux. Android bisa digunakan oleh setiap orang yang ingin menggunakannya pada perangkat mereka. Android menyediakan platform terbuka bagi para pengembang untuk menciptakan aplikasi mereka sendiri yang akan digunakan untuk bermacam peranti bergerak.

\section{PEMBAHASAN}

\subsection{Analisa Perancangan Sistem Baru}

Setelah melakukan analisa pada sistem lama, selanjutnya akan dibuat perancangan untuk sistem baru. Pada sistem baru ini dirancang sesuai dengan tujuan yang ditentukan sehingga dapat menjadi solusi dari kendala yang terdapat pada sistem sebelumnya.

\subsection{Analisis Non Fungsional}

Dengan melakukan analisis non fungsional dapat terlihat adanya kebutuhan non fungsional perangkat keras seperti sistem dibangun dengan spesifikasi hardware yang memenuhi standar minimum kebutuhan dan aplikasi ini membutuhkan adanya koneksi jaringan internet.

\subsection{Analisis Perangkat Lunak}

Perangkat lunak yang digunakan dalam pembuatan aplikasi berbasis android diantaranya adalah:

1. Sistem Operasi Windows 7

2. Adobe Photoshop

3. Eclips

4. XAMPP 


\subsection{Model Use Case Business}

Diagram Use Case Apliksi komunitas GBSA adalah sebagai berikut:

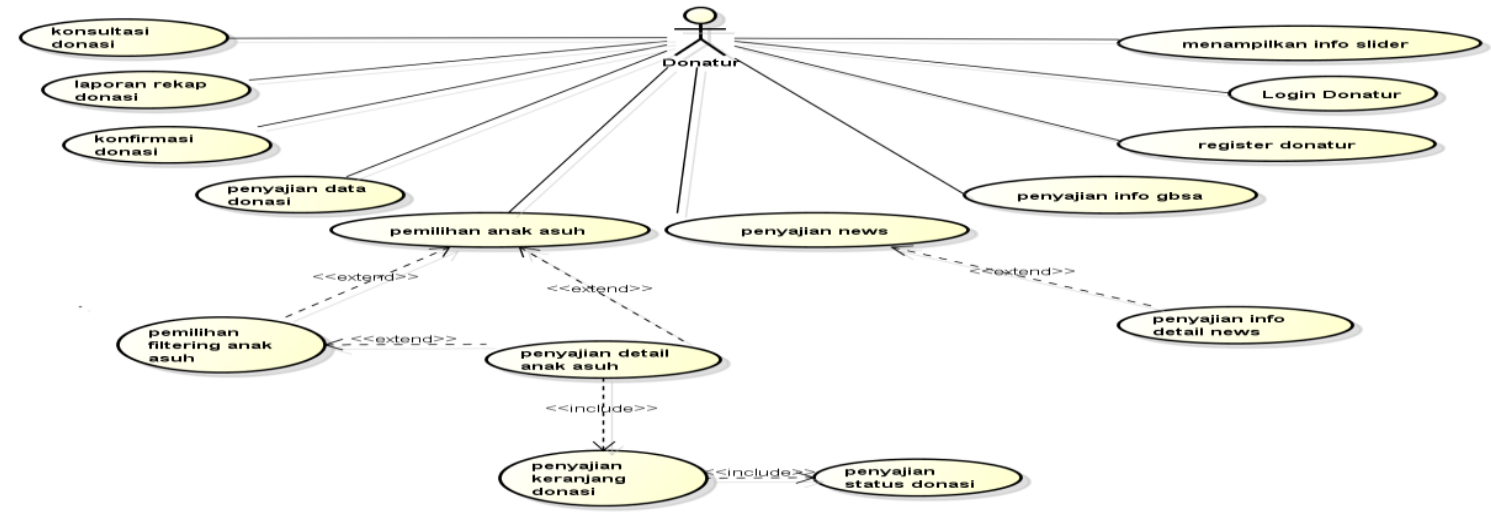

GAMBAR 3.1. Diagram Use Case

\subsection{Sequence Diagram}

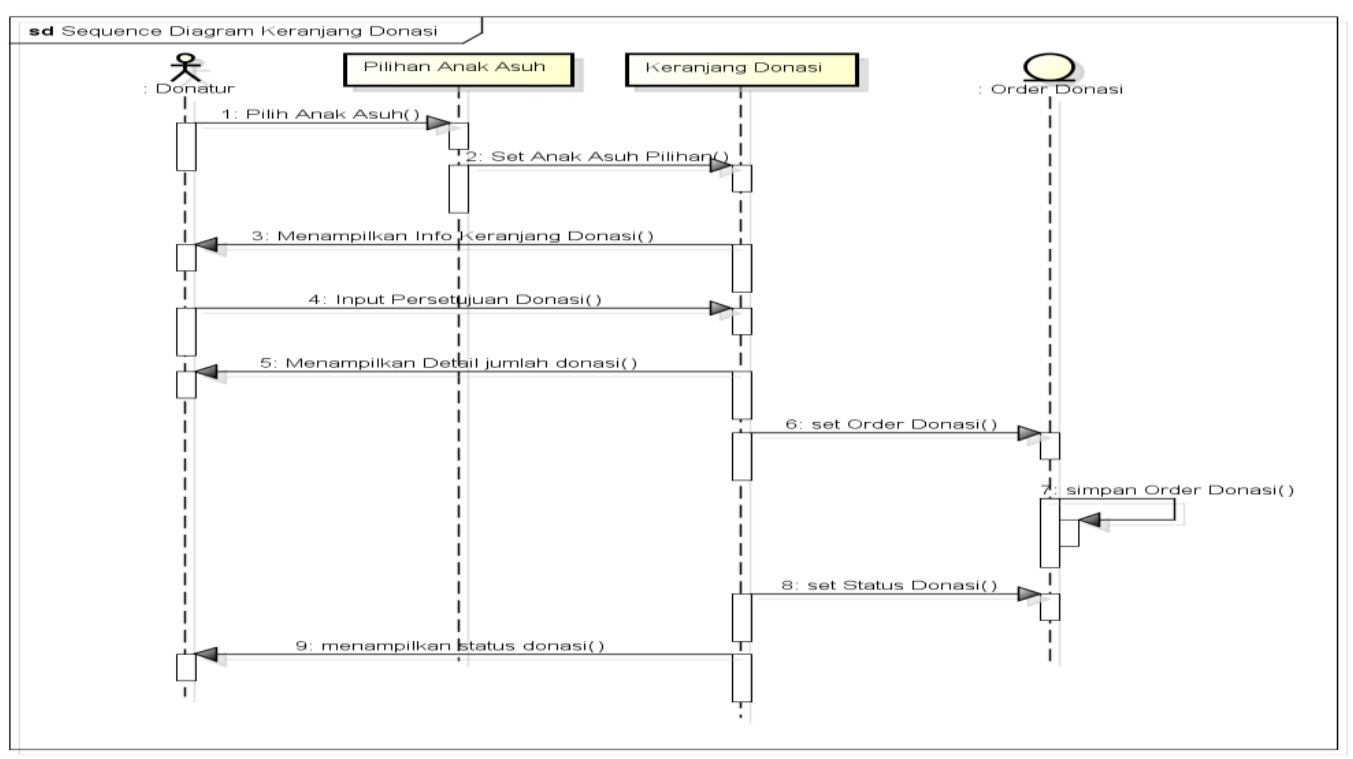

GAMBAR 3.2 Sequence Diagram Keranjang Donasi 


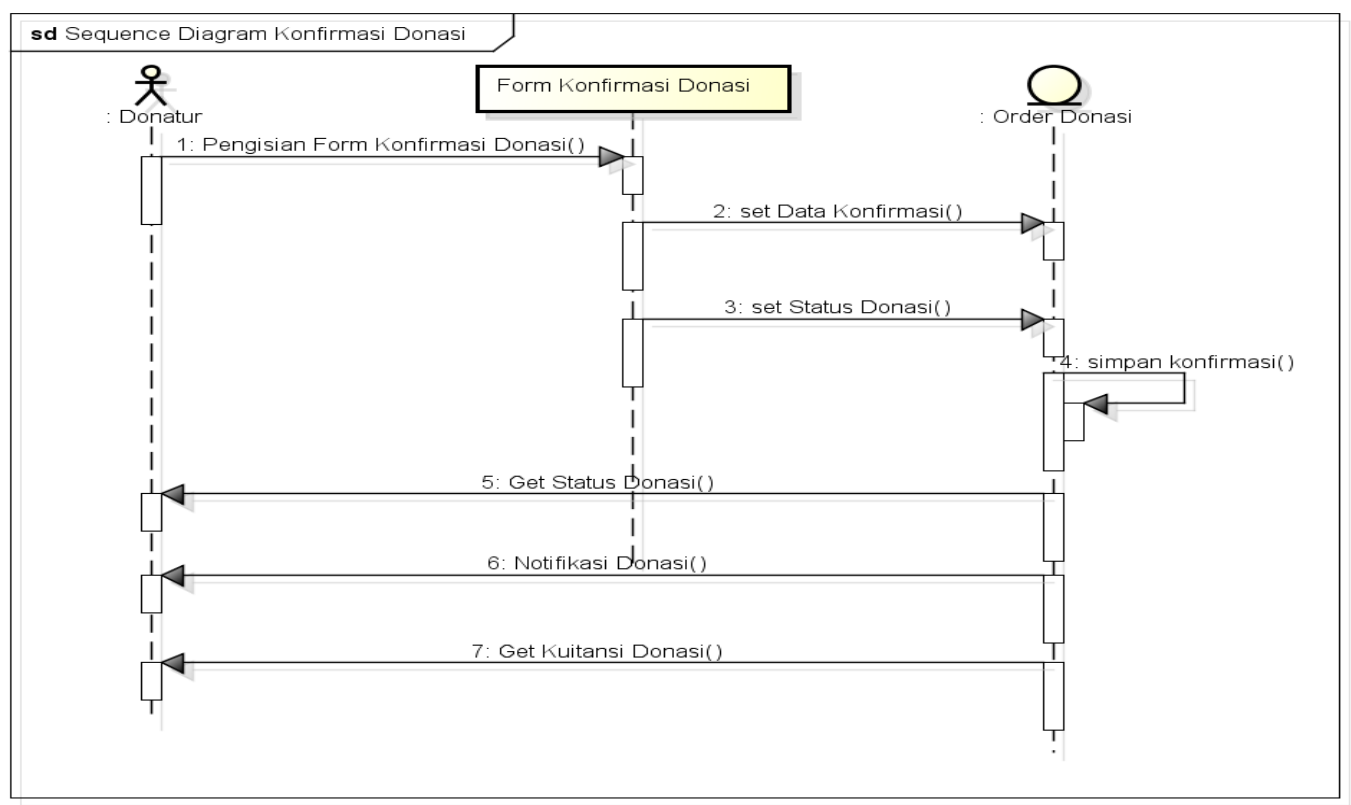

GAMBAR 3.3 Sequence Diagram Konfirmasi Donasi

\section{IMPLEMENTASI}

\subsection{Kebutuhan perangkat lunak ( Software )}

Dalam pengimplementasian perancangan aplikasi mobile berbasis android untuk komunitas GBSA ini terdapat beberapa perangkat lunak yang perlu dipersiapkan. Perangkat lunak tersebut adalah:

1. Sistem Operasi Windows 7 Starter 32 bit.

2. Bahasa pemrograman PHP \& Java.

3. DBMS : MySQL 5.5.16

4. Web Browser : Mozilla Firefox 22.0 dan Google Chrome 33.0.1750.154

5. Code Editor menggunakan Adobe Dreamweaver CS5 dan Sublime text.

6. Web Server : XAMPP.

7. Aplikasi android dibangun menggunakan SDK android yang terpasang pada IDE Eclipse Version Juno Service Release 132 bit.

8. Pertukaran data yang dilakukan menggunakan JSON.

\subsection{Implementasi Antarmuka}

Pada pengimplementasian antar muka apliakasi GBSA pada sisi website sebagai servernya adalah sebagai berikut ini : 


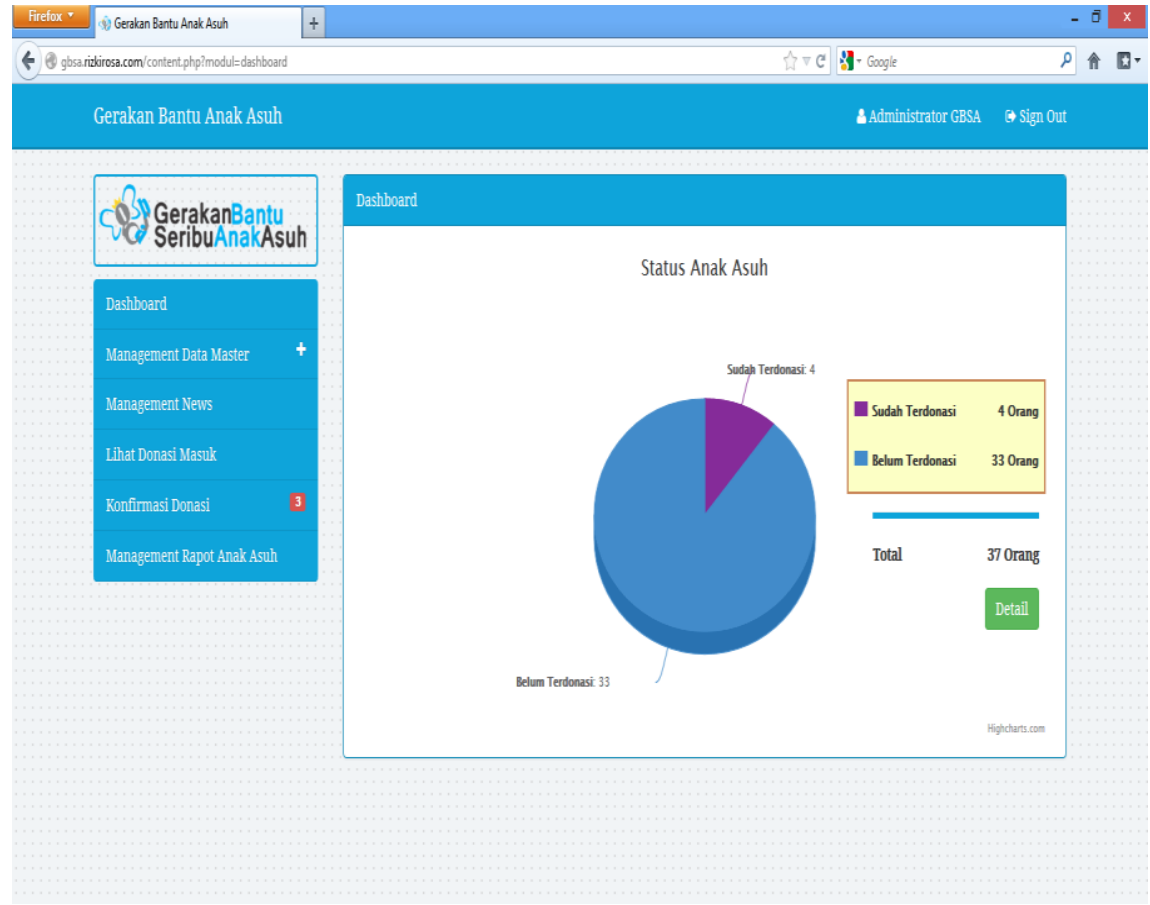

GAMBAR 4.1. Halaman Dasboard Website GBSA(Website)

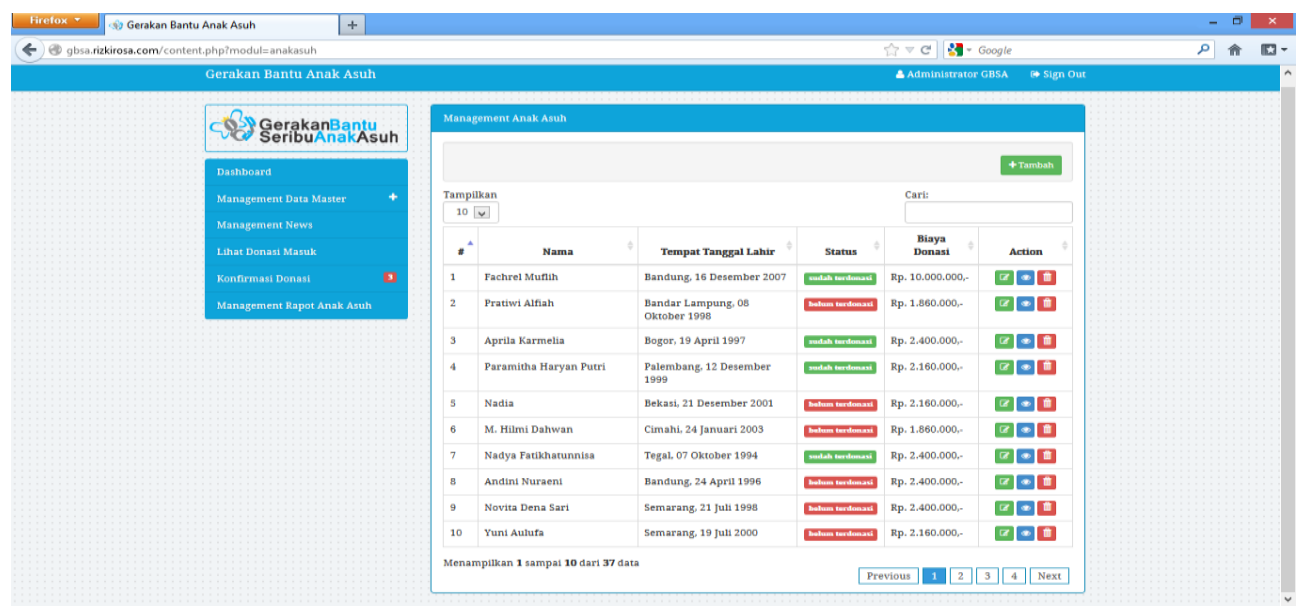

GAMBAR 4.2. Manajemen anak asuh (Website) 


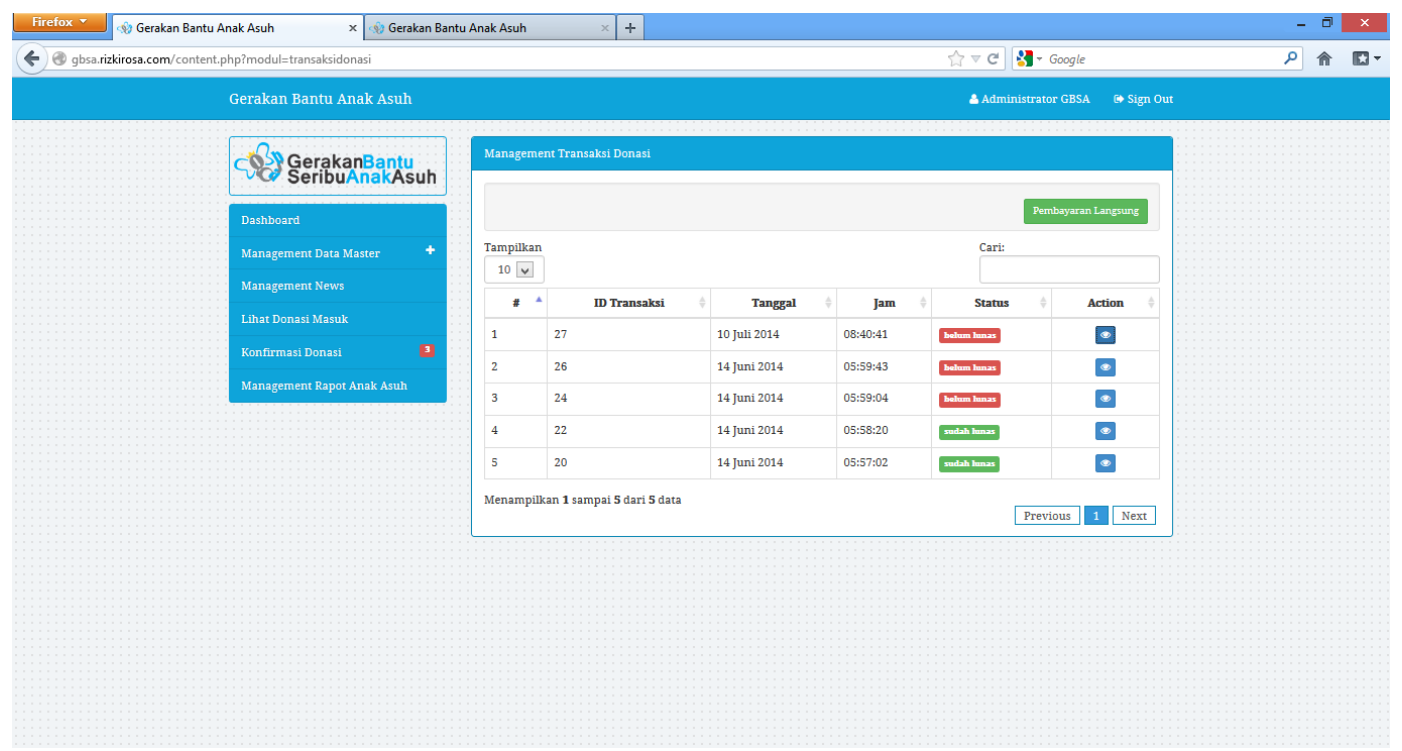

GAMBAR 4.3. Management Donasi

Pengimplementasian antar muka pada sisi aplikasi mobile berbasis android untuk komunitas GBSA adalah sebagai berikut:

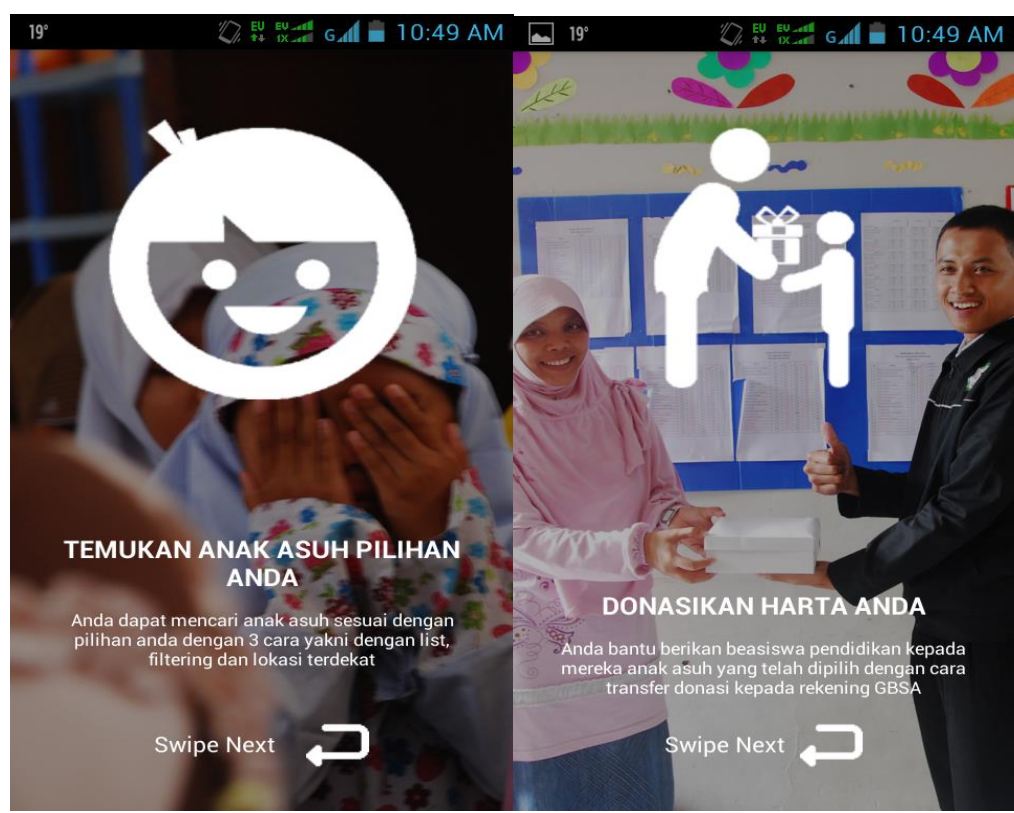

GAMBAR 4.4.2 Tampilan Awal Aplikasi Mobile Komunitas GBSA 


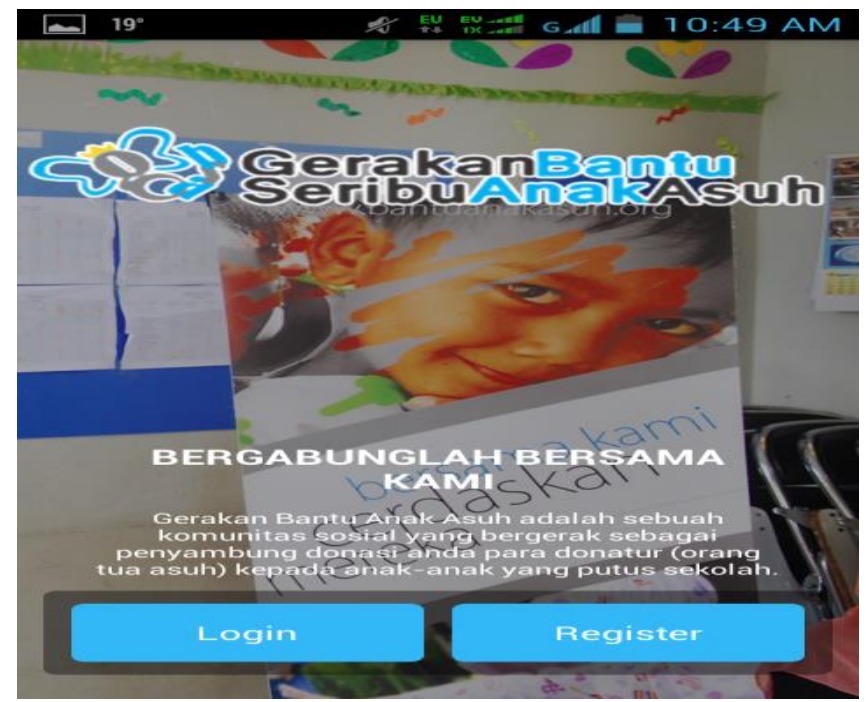

GAMBAR 4.5. Home Login dan Register
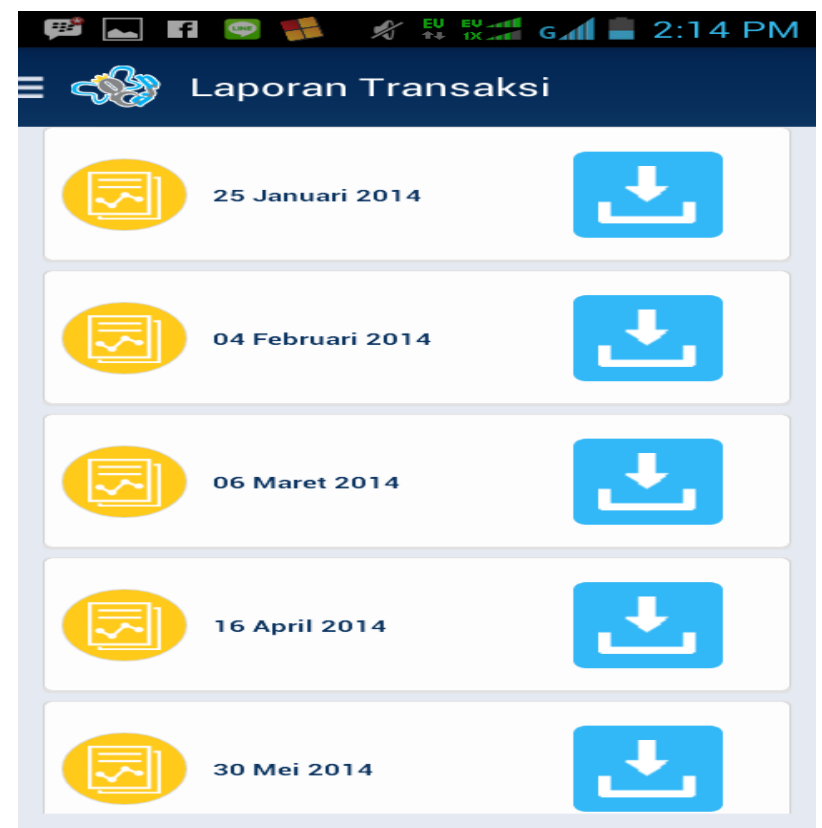

GAMBAR 4.6. Laporan Transakasi Donasi

\section{KESIMPULAN DAN SARAN}

\subsection{Kesimpulan}

Berdasarkan hasil dari penelitian, maka dapat diperoleh kesimpulan sebagai berikut:

1. Aplikasi GBSA pada platform mobile android yang dibangun telah dapat memudahkan donatur untuk mengetahui informasi dan news tentang komunitas GBSA. 
2. Aplikasi GBSA pada platform mobile android yang dibangun telah dapat memudahkan donatur dalam berkonsultasi dengan pihak service center GBSA.

3. Aplikasi GBSA pada platform mobile android yang dibangun telah memudahkan donatur dalam melakukan pemilihan anak asuh.

4. Aplikasi GBSA pada platform mobile android yang dibangun telah memudahkan donatur untuk melakukan konfirmasi pembayaran via perangkat mobile android.

\subsection{Saran}

Aplikasi gbsa pada platform android yang dibangun merupakan aplikasi pertama untuk platform mobile yang menjembatani antara donatur dengan anak asuh. Oleh karena itu perlu dilakukan pengembangan-pengembangan ke arah yang lebih baik. Adapun saran terhadap pengembangan aplikasi ini adalah:

1. Meningkatkan performansi aplikasi dengan memperhatikan penggunaan resource yang berlebih serta kecepatan pengaksesan data dari server.

2. Mengembangkan aplikasi mobile tidak hanya dapat digunakan pada platform android saja, akan tetapi dapat digunakan juga pada platform lainnya.

3. Aplikasi ini dapat dikembangkan kembali dengan menambahkan beberapa fitur lainnya seperti pencarian menggunakan nearby location untuk pencarian anak asuh, fitur download laporan perkembangan anak asuh dan lain-lain.

\section{DAFTAR PUSTAKA}

Cashman, T.J, Shelly, G.B, \& Rosenblatt, H.J. (2009). "Systems Analysis and Design Edition 9th". An imprint of course technology, cangage learning.

Fajar, D.N.H. (2009). "Modul Android Dasar dari berbagai sumber yang diedit". diakses 17 Juni 2013 dari Google.com di World Wide Web: http://www.thesigit.net/2013/03/download-modul-pemrograman-android.html.

H Safaat,Nazaruddin. 2012. “Android Pemrograman Aplikasi Mobile Smartphone dan Tablet PC Berbasis Android (Edisi Revisi) ”. Bandung:Informatika.

Huda,Arif Akbarul. 2012.“24 Jam Pintar Pemrograman Android”.Yogyakarta: Andi.

J. Simarmata, Rekayasa Web, Yogyakarta: ANDI, 2010.

Nugroho,A. (2005). “Analisis dan Perancangan Sistem Informasi Berorientasi Objek”. Informatika.

P. Roger S. Pressman, RekayasaPerangkatLunakPendekatanPraktisi (BukuSatu), vol. 1, Yogyakarta: Andi Offset dan McGraw-Hill Book Co, 2002, p. 536. 
http://arsipmoslem.wordpress.com/2007/06/28/anak-asuh-dan-anak-angkat/ (diakses 02 Juli 2014)

http://www.kemsos.go.id/modules.php?name=glosariumkesos\&letter=a （diakses 10 Juni 2014) 